\title{
Anticoagulation for Atrial Fibrillation in End-stage Kidney Disease
}

\author{
Gavin Lee ${ }^{1}$, David W Johnson ${ }^{1,2,3}$ \\ ${ }^{1}$ Department of Nephrology, Princess Alexandra Hospital, Brisbane, Australia; ${ }^{2}$ School of Medicine, The \\ University of Queensland, Brisbane, Australia; ${ }^{3}$ Translational Research Institute, Brisbane, Australia.
}

\begin{abstract}
Atrial fibrillation (AF) is the most common arrhythmia in the general population and it has been found to have a higher prevalence in end-stage kidney disease (ESKD). It is associated with a higher risk of stroke and mortality compared to those without AF. Patients with ESKD have generally been excluded from randomized controlled trials (RCTs) evaluating the efficacy of anticoagulation in reduction of stroke risk. Current observational evidence for anticoagulation for AF in the ESKD population has yielded conflicting results, but in aggregate favours a lack of benefit in stroke risk reduction with an increase in bleeding risk. There are also reports that warfarin use in ESKD patients on dialysis is associated with greater International Normalised Ratio (INR) variability and increased risk of vascular calcification and calciphylaxis (uraemic calcific arteriolopathy). RCTs are required to assess the net clinical benefit of anticoagulation in this group.

Received: 20 September 2015; Accepted after revision: 19 October 2015; Published: 29 October 2015.

Author for correspondence: Professor David W Johnson, Department of Nephrology, Level 2, ARTS Building, Princess Alexandra Hospital, Ipswich Road, Woolloongabba, Brisbane, Qld 4102, Australia. E-mail: David.Johnson2@health.qld.gov.au

How to cite: Lee G, Johnson DW. Anticoagulation for atrial fibrillation in end-stage kidney disease. Journal of Controversies in Biomedical Research 2015; 1(1):40-50.

Doi: http://dx.doi.org/10.15586/jcbmr.2015.9

Licence: This open access article is licenced under Creative Commons Attribution 4.0 International (CC BY 4.0). http://creativecommons.org/licenses/by/4.0/
\end{abstract}

\section{Introduction}

Atrial fibrillation (AF) is the most common arrhythmia in the general population, and the incidence is appreciably higher in patients with end-stage kidney disease (ESKD). A meta-analysis of twenty-five studies found the prevalence of AF in ESKD patients to be $11.6 \%$ and overall incidence to be 2.7/100 patient years (1). The prevalence appears to be increasing over time, with one analysis from the United States Renal Data System (USRDS) showing a three-fold increase in prevalence from
1992 to 2006 (2). This may reflect the increasing age and comorbidity burden in the dialysis population. The risks of mortality and stroke are significantly increased in ESKD patients with AF (26.9 and 5.2 per 100 patient-years, respectively) compared to those without (13.4 and 1.9 per 100 patient-years) (1). In the general population, systemic anticoagulation is typically indicated for reduction of stroke risk (3), but the benefit-to-risk ratio is uncertain in the ESKD population given the 
lack of randomized controlled trial (RCT) evidence. In this review, we will discuss the observational data pertaining to the effect of warfarin on stroke and bleeding risk in ESKD patients and the need for a high quality RCT to address this controversial issue.

\section{Risk of AF in CKD}

The prevalence of $\mathrm{AF}$ in the general population is approximately $1 \%$, although it appears to increase markedly with advancing age to a prevalence of $9-18 \%$ in individuals aged 80 years or older $(4,5)$. Patients with ESKD on dialysis are reported to have a prevalence of AF from $7-27 \%$ (6-9). Many of the risk factors for AF in the general population are also common in the dialysis population, including obesity, hypertension and heart failure (10). The inverse relationship between $\mathrm{AF}$ and renal function has been demonstrated in several population-based studies $(11,12)$. The Atherosclerosis Risk in Communities (ARIC) study found hazard ratios of $1.3,1.6$ and 3.2 in patients with cystatin C-based estimated glomerular filtration rate (eGFR) values of 60-89, 30-59 and $15-29 \mathrm{~mL} / \mathrm{min}$, respectively, compared to the reference population (eGFR $\geq 90 \mathrm{~mL} / \mathrm{min}$ ) (11). The Reasons for Geographic and Racial Differences in Stroke (REGARDS) study similarly reported age-, race- and sexadjusted odds ratios for prevalent $\mathrm{AF}$ to be $2.67,1.68$ and 3.52 for those with stage 1 to 2 , stage 3 and stage 4 to 5 chronic kidney disease (CKD), respectively (12).

\section{Stroke risk in $A F$ in the dialysis population}

CKD has been shown to be a risk factor for stroke in several studies. Holzmann et al. performed a very large longitudinal study of 539287 patients with 12 years of follow-up, and found an increase in ischaemic stroke risk with worsening CKD (HR 1.09, 95\% CI 1.04-1.14 for stage 2 CKD; HR 1.24, 95\% CI 1.10-1.39 for stage 3 CKD and HR 2.27, 95\% CI 1.63-2.27 for stage 4 CKD) (13). In a USRDS report, the annual stroke incidences in matched non-CKD, CKD and HD patients were $2.6 \%, 9.6 \%$ and $15.1 \%$, respectively (14).
In the general population, the absolute risk of stroke can be estimated with the CHADS2 score, or more recently the CHA2DS2-VASc score (15). The CHA2DS2-VASc score can be calculated by assigning points for Congestive heart failure $(1$ point); Hypertension (1 point); Age $\geq 75$ years (2 points); Diabetes mellitus (1 point); prior Stroke, transient ischaemic attack or thromboembolism (2 points), Vascular disease ( 1 point), Age $65-74$ years (1 point) and Sex category (female 1 point).

In the absence of a specific tool validated to assess stroke risk in the dialysis population, several studies have suggested a correlation between higher CHADS2 score and stroke risk in this group $(8,16-18)$. Olesen et al. found the unadjusted incidence of stroke to be $1.99,2.35$ and 3.55 events per 100 person-years in dialysis patients with CHADS2 scores of 0,1 and 2, respectively (16). Of note, the stroke risk in every category of CHADS2 score was higher than a comparison group of non-dialysis patients with $\mathrm{AF}$, suggesting the CHADS2 score may underestimate stroke risk in dialysis patients.

\section{Warfarin in dialysis patients}

Warfarin (Wisconsin Alumni Research Foundation coumARIN) is a vitamin $\mathrm{K}$ antagonist that inhibits vitamin $\mathrm{K}$ epoxide reductase, interfering with the production of vitamin $\mathrm{K}$-dependent coagulation factors II, VII, IX and X, protein C and protein S (19). There is reasonable evidence that warfarin may accelerate vascular calcification in dialysis patients, potentially via antagonism of the vitamin K-dependent matrix G1a protein (MGP), a potent inhibitor of vascular calcification. Mice that lack MGP were found to die within two months of birth due to severe arterial calcification leading to vessel rupture (20). In humans, a loss-of-function mutation in the gene encoding MGP (Keutel syndrome) leads to widespread large vessel vascular calcification and abnormal cartilage calcification (21).

The effect of warfarin on MGP and vascular calcification has been demonstrated in a mouse model, where administration of warfarin was found to induce arterial medial calcification, associated with a reduction in 
MGP mRNA expression, which could be reversed with vitamin $\mathrm{K}$ treatment (22). McCabe et al. (23) similarly reported increased vascular calcification in rats with CKD on warfarin, which was also blunted by vitamin $\mathrm{K}$. In a retrospective study of 108 haemodialysis (HD) patients, an association was found between duration of warfarin exposure and degree of aortic valve calcification after adjustment for dialysis vintage, calcium and calcitriol intake (24). Furthermore, a recent Japanese study found an 11-fold risk in HD patients on warfarin for calciphylaxis (uraemic calcific arteriolopathy), an uncommon complication of ESKD characterised by skin ulceration and necrosis with small vessel medial calcification and intimal proliferation (25).

The time in therapeutic range (TTR) of the international normalised ratio (INR) is an important predictor of warfarin efficacy and safety in the general population (26). A systematic review of 47 studies reporting INR control found approximately $60 \%$ of INR measurements to be within the therapeutic range (27). Patients on $\mathrm{HD}$ tend to have lower warfarin dose requirements and greater INR variability (28). To further add to this unpredictability, anticoagulation catheter-locking solutions may interfere with INR measurement when samples are collected from the catheter directly (29). Two studies have attempted to reduce INR variability with daily low-dose vitamin $\mathrm{K}$ supplementation (30) and thrice-weekly post-HD warfarin dosing (31). Both interventions were associated with modest improvements in TTR but their effects on bleeding risk remained unclear.

\section{Uncertainty of warfarin net benefit}

Warfarin and, to a lesser extent, antiplatelet agents have been found to reduce the stroke risk in patients with AF. A 2007 metaanalysis of 29 trials including 28044 patients found relative reductions in stroke risk of $64 \%$ with warfarin and $22 \%$ with antiplatelet agents (3). The 2014 ACC/AHA (American College of Cardiology/American Heart Association) guideline for management of patients with atrial fibrillation recommends oral anticoagulation if the CHA2DS2-VASc score is two or greater (32). The guideline extends this recommendation to patients with ESKD on haemodialysis. However, there have been no RCTs (RCTs) investigating the benefit of anticoagulation for stroke risk in the ESKD population, who have largely been excluded from the trials in the general population. Consequently, the Kidney Disease Improving Global Outcomes (KDIGO) Guidelines $(33,34)$ caution that, given the lack of RCTs, the risk-to-benefit ratio of routine anticoagulation for primary or secondary prevention of stroke remains uncertain. More recently, the International Society for Peritoneal Dialysis (ISPD) Cardiovascular Guidelines suggest "individualization of warfarin prescription for prevention of stroke in peritoneal dialysis patients with atrial fibrillation in view of an increased risk of bleeding and uncertain effects on cerebrovascular outcomes. (2D)" $(35,36)$.

Clinical equipoise exists among nephrologists regarding the benefit-to-risk ratio of anticoagulation for stroke risk reduction in the dialysis population. A survey of 56 Canadian nephrologists found agreement in the majority $(72 \%)$ that there was a state of uncertainty regarding this clinical question (37). Each nephrologist was presented six clinical scenarios and given a choice as to whether they were likely to start warfarin, unlikely to start warfarin or were uncertain. The level of uncertainty increased when a patient was on haemodialysis and when risk factors for bleeding were present, including a history of gastrointestinal bleeding or a risk for falls.

\section{Stroke and bleeding risk with warfarin}

In the absence of a RCT addressing the net benefit of warfarin for AF in ESKD patients, the best available data so far remains observational in nature. Chan et al. performed a retrospective cohort analysis of 1671 incident HD patients with atrial fibrillation followed up for a mean of 1.6 years (38). The use of warfarin was associated with an increased risk of stroke (hazard ratio [HR] 1.93, 95\% CI 1.29-2.90) after Cox regression analysis, and propensity matching did not significantly affect the findings of the analysis. There was a four-fold increase in mortality from stroke $(\mathrm{p}=0.009)$ and increase in hospitalisation from stroke (HR 1.89, 95\% CI 1.16-3.09), but no significant difference in rates of 
hospitalisation for bleeding (HR 1.04, 95\% CI 0.73-1.46). The classification of haemorrhagic stroke as a stroke outcome in this study may have partially accounted for the reported increase in stroke risk.

Wizemann et al. sampled 2188 patients with AF out of 17513 HD patients from the international Dialysis Outcomes and Practice Patterns Study (DOPPS) (8). They found a significant association between warfarin and increased stroke risk in patients aged over 75 years, with reported hazard ratios of 1.29 (95\% CI $0.45-3.68)$, 1.35 (95\% CI 0.69-2.63) and 2.17 (95\% CI $1.04-4.53)$ in the patient groups aged $<65$, $66-75$ and $>75$ respectively. Patients with a CHADS2 score of 3 or greater on warfarin were also found to have higher stroke risk, although this finding was explained by the age component of the score rather than the other variables. Bleeding risk data were not provided in this study.

Phelan et al. compared stroke and bleeding risks in 141 HD patients on warfarin, 704 HD patients not on warfarin and 3266 nondialysis patients on warfarin (28). In the patients with $\mathrm{AF}$, the HD warfarin group had a higher risk of ischaemic stroke than the non-dialysis warfarin group $(2.2$ vs 0.4 events per 100 person-years, $p=0.024)$. The incidence of major haemorrhage per 100 patient-years was significantly greater in the HD warfarin group (10.8) compared to 2.1 in the non-HD warfarin group $(\mathrm{p}<0.001)$, but similar to the HD non-warfarin group (8.0, $\mathrm{p}=0.593)$.

In contrast, Winkelmayer et al. evaluated outcomes in $\mathrm{HD}$ patients with incident AF rather than pre-existing $\mathrm{AF}$ by use of an inception cohort of older patients aged 66 years or older at the time of dialysis commencement (39). They identified 2313 patients with new AF who survived at least 30 days from discharge, and compared 237 patients started on warfarin within 30 days of discharge with 948 propensity-matched patients not on warfarin. There was no significant difference in ischaemic stroke risk (HR 0.92, 95\% CI 0.61-1.37) but the risk of haemorrhagic stroke was doubled in the warfarin group (HR 2.38, 95\% CI 1.154.96). The use of an inception cohort and new-user design may have reduced bias related to variations in risk with disease duration or medication (40), which may have accounted for the difference in reported ischaemic stroke risk compared to the previous three studies. The risk of mortality and gastrointestinal bleeding was similar between the two groups. The unexpected lack of association between warfarin and increased gastrointestinal bleeding risk may have been explained by the wide use of gastroprotective medication in the cohort, with $70 \%$ of patients being on a proton-pump inhibitor or histamine- 2 antagonist.

Olesen et al. searched Danish national registries to identify 901 patients requiring renal replacement therapy (RRT) discharged from hospital with a diagnosis of nonvalvular atrial fibrillation between 1997 and 2008 (16). Warfarin use was associated with a lower risk of stroke or systemic thromboembolism (HR 0.44, 95\% CI 0.26$0.74, p=0.002$ ), but was not associated with bleeding risk (HR 1.27, 95\% CI 0.91-1.77, $\mathrm{p}=0.15)$. The finding of reduced stroke risk may have been explained by the inclusion in the study group of peritoneal dialysis (PD) patients and kidney transplant recipients, who may have had different risk-to-benefit profiles on warfarin compared to HD patients. Alternatively, the results may have been confounded by indication.

Wakasugi et al. performed a prospective multicenter cohort study of 60 Japanese HD patients with chronic sustained AF (18). They found no difference in the incidence of new ischaemic stroke between 28 warfarin users and 32 non-warfarin users (HR 3.36, 95\% CI 0.94-11.23) after adjustment for CHADS2 score. There was also no difference in major bleeding risk (HR 0.85, 95\% CI $0.19-3.64)$ or all-cause mortality (HR 1.00, 95\% CI 0.40-2.52). Although the sample size was limited, this study provides further evidence towards the lack of benefit of warfarin for stroke risk in HD patients with AF.

Shah et al. conducted a population based retrospective cohort study of 1626 Canadian dialysis (HD and PD) patients aged 65 years or older admitted to hospital with a diagnosis of AF (17). After adjustment for potential confounders, warfarin was not 
associated with risk of stroke (HR 1.14, 95\% CI 0.78-1.67) but was associated with higher bleeding risk (HR 1.44, 95\% CI 1.131.85). Although this study had a large sample size, a major limitation was the inclusion criterion used to identify dialysis patients, defined as patients who had undergone three or more haemodialysis or peritoneal dialysis procedures in the prior year, which may have included a significant number of patients with acute kidney injury. Furthermore, patients were assigned to the warfarin group if they filled a prescription for warfarin in the first 30 days after discharge, and the duration of warfarin use was not captured.

A meta-analysis by $\mathrm{Li}$ et al. (41) of six observational cohort studies $(8,16-18,38$, 39) provides the highest level of evidence so far until a RCT can be implemented. For the assessment of stroke risk, a total of 9816 participants from the six studies were included with 2466 of these patients on warfarin. No significant association was observed between warfarin use and the risk of stroke (HR 1.23, 95\% CI 0.80-1.87, $\mathrm{p}=0.347$ ), although the validity of this result is questionable in view of the statistically significant, high-level trial heterogeneity that was identified $(\mathrm{I} 2=79.2 \%, \mathrm{p}=0.000)$. A subgroup analysis of the four trials that included only HD patients found an increase in stroke risk with warfarin use (HR 1.57, 95\% CI 1.09-2.25, $\mathrm{p}=0.015)$. For the assessment of bleeding risk, a total of 6571 patients in five studies were included with 1957 of these patients on warfarin. The fixed-effects model was used due to the absence of significant heterogeneity $(\mathrm{I} 2=20.4 \%, \quad \mathrm{p}=0.285)$ and found that warfarin significantly increased bleeding risk $(\mathrm{HR}=1.20,95 \% \mathrm{CI} 1.03-1.39, \mathrm{p}=0.019)$.

Although the accumulating evidence suggests an absence of benefit for stroke risk for ESKD patients on warfarin and perhaps even an increased stroke risk in HD patients, several limitations exist. Due to the observational nature of the data, indication bias with residual confounding cannot be excluded. Patients on warfarin were likely to have a higher risk of stroke, as assessed by their clinician, and this may not have been fully adjusted for by covariates. The use of registry data may have led to ascertainment bias, whereby more severe stroke or bleeding events were preferentially recorded. Previous warfarin use was not ubiquitously recorded and patients who had previously ceased warfarin therapy due to a bleeding event may have been included in the non-warfarin group. Finally, there was significant heterogeneity in stroke risk among the six studies included in the metaanalysis, which may be accounted for by differences in study design, study population and covariate adjustment.

\section{Use of newer anticoagulants}

The novel oral anticoagulants include the direct thrombin inhibitor, dabigatran, and the factor $\mathrm{Xa}$ inhibitors, apixaban and rivaroxaban. Several recent large RCTs have shown these agents to be non-inferior to warfarin for stroke risk reduction in patients with AF (42-44). The use of these drugs in ESKD patients appears to be steadily rising, with one recent study by Chan et al. reporting $5.9 \%$ of anticoagulated HD patients on dabigatran or rivaroxaban (45). Despite this, there are significant concerns with the use of the novel anticoagulants in ESKD. Firstly, patients with moderate to severe CKD have generally been excluded from these trials, so there are no data to support the efficacy of these agents in this population. Secondly, there are no effective options for anticoagulation reversal in the setting of major bleeding or requirement for an urgent surgery, except for dabigatran, for which idarucizumab has been found to rapidly and effectively reverse the anticoagulant effect (46). Finally, these drugs are invariably excreted renally to some extent, which can lead to accumulation in patients with CKD. The study by Chan et al. found a higher risk of hospitalization or death from bleeding with dabigatran (HR 1.48, 95\% CI 1.21-1.81) or rivaroxaban (HR 1.38, 95\% CI 1.03-1.83) compared to warfarin in anticoagulated HD patients (45).

Dabigatran is primarily renally excreted, with $80-85 \%$ of the drug excreted unchanged in the urine. The half-life of the drug increases from 9 hours with normal renal function to 25-30 hours in patients with creatinine clearance $<30 \mathrm{~mL} / \mathrm{min}(47)$. It is dialysable, with $50-60 \%$ of the drug removed after a 4 hours of haemodialysis (48). Rivaroxaban undergoes 33\% renal 
excretion via proximal tubule secretion, but is not dialysable due to $92-95 \%$ protein binding (49).

Apixaban is $27 \%$ excreted as unchanged drug in the urine and $14 \%$ of the drug is removed via dialysis (50). A single dose pharmacokinetic study of apixaban compared eight HD patients with eight controls with normal renal function and found a $36 \%$ increase in area under the curve (AUC) (51). Following this study, FDA labeling for the product changed from "no data to inform the use of patients with creatinine clearance $<15 \mathrm{~mL} / \mathrm{min}$ or on dialysis" to a recommended dose in ESKD of $5 \mathrm{mg}$ twice daily or $2.5 \mathrm{mg}$ twice daily if the patient is aged over 80 years or body weight is less than $60 \mathrm{~kg}$ (50). However, the pharmacokinetics of cumulative drug dosing remains to be evaluated, and there are currently no data on bleeding risk or efficacy in this population.

\section{Need for a RCT}

Given the uncertainty that exists regarding the benefit-to-risk ratio of anticoagulation for AF in ESKD patients, a high-quality RCT is required to answer this clinical question. Previous observational studies have yielded conflicting results and in aggregate have shown no reduction in stroke risk but an increase in bleeding risk. Although there is clear evidence for the benefit of warfarin for stroke risk reduction in the general population (3) and evidence that this benefit extends to stage 3 CKD (52), it cannot reasonably be extrapolated to the ESKD group. As an example highlighting this point, another intervention commonly used in the CKD population, HMG-CoA reductase inhibitor (statin) therapy for cardiovascular risk reduction, was found to significantly reduce risk of death and major cardiovascular events in patients with CKD not requiring dialysis (53), but this benefit did not extend to patients on dialysis (54).

Several challenges arise in designing and implementing a RCT on warfarin use in HD. Firstly, it may be considered unethical to randomise patients to the use of warfarin if previous observational data have shown a clear increase in bleeding risk without a significant benefit in stroke risk. However, there remains a degree of uncertainty as to the net benefit, and a rigorous RCT would provide a higher level of evidence to answer this question than the previous observational studies (55). Secondly, nephrologists and patients may have strong preferences for or against anticoagulation that may limit recruitment, although in a Canadian survey of nephrologists, the majority indicated that they would be willing to enroll their patients in such a trial (37). Finally, funding is unlikely to come from the pharmaceutical industry as generic warfarin is cheap and bioequivalent to brand-name warfarin (56), so it would likely need to be sourced publicly. An alternative would be a randomised placebo-controlled trial of one of the newer oral anticoagulants.

In conclusion, patients with ESKD have generally been excluded from RCTs of anticoagulation for $\mathrm{AF}$, although the risks of $\mathrm{AF}$ and stroke have been found to be higher in this population. Several considerations arise when prescribing warfarin in ESKD patients, including greater INR variability and increased risk of vascular calcification and calciphylaxis. Numerous observational studies have failed to identify an association between warfarin use and risk of stroke, but have identified a clear association with heightened bleeding risk. There is a need for a RCT to answer this clinical question, although several financial and ethical barriers need to be overcome to implement such a trial.

\section{Conflict of Interest}

David Johnson has received consultancy fees, research funds, travel sponsorships and speaker's honoraria from Fresenius Medical Care and Baxter Healthcare. Gavin Lee declares no potential conflicts of interest with respect to research, authorship and/or publication of this article.

\section{References}

1. Zimmerman D, Sood MM, Rigatto C, Holden RM, Hiremath S, Clase CM. Systematic review and meta-analysis of incidence, prevalence and outcomes of atrial fibrillation in patients on dialysis. Nephrol Dial Transplant. 2012;27(10):3816-22. 
http:/ / dx.doi.org/ 10.1093/ndt/gfs416 PMid:23114904

2. Winkelmayer WC, Patrick AR, Liu J, Brookhart MA, Setoguchi S. The increasing prevalence of atrial fibrillation among hemodialysis patients. J Am Soc Nephrol . 2011;22(2):349-57.

http:/ / dx.doi.org/ 10.1681/ASN.20100504 59

PMid:21233416 PMCid:PMC3029907

3. Hart RG, Pearce LA, Aguilar MI. Metaanalysis: antithrombotic therapy to prevent stroke in patients who have nonvalvular atrial fibrillation. Ann Intern Med. 2007;146(12):857.

http:/ / dx.doi.org/ 10.7326/0003-4819-

146-12-200706190-00007

PMid:17577005

4. Go AS, Hylek EM, Phillips KA, Chang Y, Henault LE, Selby JV, et al. Prevalence of diagnosed atrial fibrillation in adults: national implications for rhythm management and stroke prevention: the AnTicoagulation and Risk Factors in Atrial Fibrillation (ATRIA) Study. Jama. 2001;285(18):2370-5.

http://dx.doi.org/10.1001/jama.285.18.23 70

5. McManus DD, Rienstra M, Benjamin EJ. An Update on the Prognosis of Patients With Atrial Fibrillation. Circulation. 2012;126(10):e143-e6.

http:/ /dx.doi.org/10.1161/CIRCULATIONA HA. 112.129759

PMid:22949543 PMCid:PMC3678907

6. Wetmore JB, Mahnken JD, Rigler SK, Ellerbeck EF, Mukhopadhyay P, Spertus JA, et al. The prevalence of and factors associated with chronic atrial fibrillation in Medicare/Medicaid-eligible dialysis patients. Kidney Int. 2012;81(5):469-76. http:/ / dx.doi.org/ 10.1038/ki.2011.416 PMid:22189842 PMCid:PMC3891593

7. Genovesi S, Pogliani D, Faini A, Valsecchi MG, Riva A, Stefani F, et al. Prevalence of atrial fibrillation and associated factors in a population of long-term hemodialysis patients. Am J Kidney Dis. 2005;46(5):897902. http://dx.doi.org/10.1053/j.ajkd.2005.07. 044 PMid:16253730

8. Wizemann V, Tong L, Satayathum S, Disney A, Akiba T, Fissell RB, et al. Atrial fibrillation in hemodialysis patients: clinical features and associations with anticoagulant therapy. Kidney Int. 2010;77(12):1098-106.

http:/ / dx.doi.org/ 10.1038/ki.2009.477 PMid:20054291

9. Atar I, Konas D, Acikel S, Kulah E, Atar A, Bozbas $\mathrm{H}$, et al. Frequency of atrial fibrillation and factors related to its development in dialysis patients. Int $\mathrm{J}$ Cardiol. 2006;106(1):47-51.

http://dx.doi.org/10.1016/j.ijcard.2004.12 .048

PMid:16321665

10. Schnabel RB, Sullivan LM, Levy D, Pencina MJ, Massaro JM, D'Agostino RB, Sr., et al. Development of a risk score for atrial fibrillation (Framingham Heart Study): a community-based cohort study. Lancet. 2009;373(9665):739-45.

http://dx.doi.org/10.1016/S0140-

6736(09)60443-8

11. Alonso A, Lopez FL, Matsushita K, Loehr LR, Agarwal SK, Chen LY, et al. Chronic Kidney Disease Is Associated With the Incidence of Atrial Fibrillation: The Atherosclerosis Risk in Communities (ARIC) Study. Circulation. 2011;123(25):2946-53. http://dx.doi.org/10.1161/CIRCULATIONA HA. 111.020982

PMid:2 1646496 PMCid:PMC3139978

12. Baber U, Howard VJ, Halperin JL, Soliman EZ, Zhang X, McClellan W, et al. Association of Chronic Kidney Disease With Atrial Fibrillation Among Adults in the United States: REasons for Geographic and Racial Differences in Stroke (REGARDS) Study. Circ Arrhythm Electrophysiol. 2010;4(1):26-32.

http:/ /dx.doi.org/ 10.1161/CIRCEP.110.95 7100

PMid:21076159 PMCid:PMC3049935

13. Holzmann MJ, Aastveit A, Hammar N, Jungner I, Walldius G, Holme I. Renal 
dysfunction increases the risk of ischemic and hemorrhagic stroke in the general population. Ann Med. 2012;44(6):607-15. http:/ /dx.doi.org/ 10.3109/07853890.2011 .582136

PMid:21612332

14. System USRD. USRDS 2005/2006/2007 Annual Data Report: Atlas of End Stage Renal Disease in the United States. National Institutes of Diabetes and Digestive and Kidney Diseases, Besthesda, MD: National Institutes of Health, 2005.

15. Lip GY, Nieuwlaat R, Pisters R, Lane DA, Crijns HJ. Refining clinical risk stratification for predicting stroke and thromboembolism in atrial fibrillation using a novel risk factor-based approach: the euro heart survey on atrial fibrillation. Chest. 2010;137(2):263-72.

http://dx.doi.org/10.1378/chest.09-1584 PMid: 19762550

16. Olesen JB, Lip GY, Kamper AL, Hommel K, Kober L, Lane DA, et al. Stroke and bleeding in atrial fibrillation with chronic kidney disease. N Engl J Med. 2012;367(7):625-35.

http:// dx.doi.org/ 10.1056/NEJMoa1 1055 94

PMid:22894575

17. Shah M, Avgil Tsadok M, Jackevicius CA, Essebag V, Eisenberg MJ, Rahme E, et al. Warfarin use and the risk for stroke and bleeding in patients with atrial fibrillation undergoing dialysis. Circulation. 2014;129(11):1196-203.

http:/ / dx.doi.org/10.1161/CIRCULATIONA HA. 113.004777

PMid:24452752

18. Wakasugi M, Kazama JJ, Tokumoto A, Suzuki K, Kageyama S, Ohya K, et al. Association between warfarin use and incidence of ischemic stroke in Japanese hemodialysis patients with chronic sustained atrial fibrillation: a prospective cohort study. Clin Exp Nephrol. 2014;18(4):662-9.

http://dx.doi.org/10.1007/s10157-0130885-6

PMid:24113782
19. Kruger T, Floege J. Vitamin K antagonists: beyond bleeding. Semin Dial. 2014;27(1):37-41.

http://dx.doi.org/10.1111/sdi.12175

PMid:24400802

20. Luo G, Ducy P, McKee MD, Pinero GJ, Loyer E, Behringer RR, et al. Spontaneous calcification of arteries and cartilage in mice lacking matrix GLA protein. Nature. 1997;386(6620):78-81.

http://dx.doi.org/10.1038/386078a0

PMid:9052783

21. Meier M, Weng LP, Alexandrakis E, Ruschoff J, Goeckenjan G. Tracheobronchial stenosis in Keutel syndrome. Eur Respir J. 2001;17(3):566-9. http://dx.doi.org/ 10.1183/09031936.01.1 7305660

PMid:11405537

22. Kruger $\mathrm{T}$, Oelenberg $\mathrm{S}$, Kaesler $\mathrm{N}$, Schurgers LJ, van de Sandt AM, Boor P, et al. Warfarin induces cardiovascular damage in mice. Arterioscler Thromb Vasc Biol. 2013;33(11):2618-24.

http://dx.doi.org/10.1161/ATVBAHA. 113. 302244

PMid:23990204

23. McCabe KM, Booth SL, Fu X, Shobeiri $\mathrm{N}$, Pang JJ, Adams MA, et al. Dietary vitamin $\mathrm{K}$ and therapeutic warfarin alter the susceptibility to vascular calcification in experimental chronic kidney disease. Kidney Int. 2013;83(5):835-44.

http:/ /dx.doi.org/ 10.1038/ki.2012.477

PMid:23344475

24. Holden RM, Sanfilippo AS, Hopman WM, Zimmerman D, Garland JS, Morton AR. Warfarin and aortic valve calcification in hemodialysis patients. J Nephrol. 2007;20(4):417-22.

PMid:17879207

25. Hayashi M, Takamatsu I, Kanno $\mathrm{Y}$, Yoshida T, Abe T, Sato Y. A case-control study of calciphylaxis in Japanese end-stage renal disease patients. Nephrol Dial Transplant. 2012;27(4):1580-4.

http:/ / dx.doi.org/ 10.1093/ndt/gfr658

PMid:22121234 
26. Hylek EM, Go AS, Chang Y, Jensvold NG, Henault LE, Selby JV, et al. Effect of intensity of oral anticoagulation on stroke severity and mortality in atrial fibrillation. $\mathrm{N}$ Engl J Med. 2003;349(11):1019-26. http:/ / dx.doi.org/ 10.1056/NEJMoa02291 3

PMid: 12968085

27. Wan Y, Heneghan C, Perera R, Roberts $\mathrm{N}$, Hollowell J, Glasziou $\mathrm{P}$, et al. Anticoagulation control and prediction of adverse events in patients with atrial fibrillation: a systematic review. Circ Cardiovasc Qual Outcomes. 2008;1(2):8491.

http:/ / dx.doi.org/ 10.1161/CIRCOUTCOM

ES. 108.796185

PMid:20031794

28. Phelan PJ, O'Kelly P, Holian J, Walshe JJ, Delany C, Slaby J, et al. Warfarin use in hemodialysis patients: what is the risk? Clin Nephrol. 2011;75(3):204-11.

http:/ / dx.doi.org/ 10.5414/CN106481

PMid:21329630

29. Rioux JP, De Bortoli B, Querin S, Deziel C, Troyanov S, Madore F. Measurement of the international normalized ratio (INR) in hemodialysis patients with heparin-locked central venous catheters: evaluation of a novel blood sampling method. J Vasc Access.

PMid: 19670171

30. Rombouts EK, Rosendaal FR, Van Der Meer FJ. Daily vitamin K supplementation improves anticoagulant stability. J Thromb Haemost: JTH. 2007;5(10):2043-8.

http:/ / dx.doi.org/10.1111/j.1538-

7836.2007.02715.x

PMid: 17666020

31. Sood MM, Rigatto C, Bueti J, Lang C, Miller L, PonnamPalam A, et al. Thrice weekly warfarin administration in haemodialysis patients. Nephrol Dial Transplant. 2009;24(10):3162-7.

http: / / dx.doi.org/ 10.1093/ndt/gfp252

PMid: 19487735

32. January CT, Wann LS, Alpert JS, Calkins H, Cigarroa JE, Cleveland JC, et al. 2014 AHA/ACC/HRS Guideline for the Management of Patients With Atrial Fibrillation: A Report of the American
College of Cardiology/American Heart Association Task Force on Practice Guidelines and the Heart Rhythm Society. Circulation. 2014;130(23):e199-e267. http:/ /dx.doi.org/ 10.1161/CIR.000000000 0000041

PMid:24682347

33. K/DOQI clinical practice guidelines for cardiovascular disease in dialysis patients. Am J Kidney Dis. 2005;45(4 Suppl 3):S1153.

34. Herzog CA, Asinger RW, Berger AK, Charytan DM, Diez J, Hart RG, et al. Cardiovascular disease in chronic kidney disease. A clinical update from Kidney Disease: Improving Global Outcomes (KDIGO). Kidney Int. 2011;80(6):572-86. http:/ /dx.doi.org/ 10.1038/ki.2011.223 PMid:21750584

35. Wang AY, Brimble KS, Brunier G, Holt SG, Jha V, Johnson DW, et al. ISPD Cardiovascular and Metabolic Guidelines in Adult Peritoneal Dialysis Patients Part II Management of Various Cardiovascular Complications. Perit Dial Int. 2015;35(4):388-96.

http: / /dx.doi.org/10.3747 / pdi.2014.00278 PMid:26228783

36. Wang AY, Brimble KS, Brunier G, Holt SG, Jha V, Johnson DW, et al. ISPD Cardiovascular and Metabolic Guidelines in Adult Peritoneal Dialysis Patients Part I Assessment and Management of Various Cardiovascular Risk Factors. Perit Dial Int. 2015;35(4):379-87.

http: / /dx.doi.org/10.3747/pdi.2014.00279 PMid:26228782

37. Juma S, Thomson BK, Lok CE, Clase CM, Blake PG, Moist L. Warfarin use in hemodialysis patients with atrial fibrillation: decisions based on uncertainty. BMC Nephrol. 2013;14:174.

http:/ /dx.doi.org/ 10.1186/1471-2369-14174

PMid:23941163 PMCid:PMC3751624

38. Chan KE, Lazarus JM, Thadhani R, Hakim RM. Warfarin use associates with increased risk for stroke in hemodialysis patients with atrial fibrillation. J Am Soc Nephrol. 2009;20(10):2223-33. 
http://dx.doi.org/ 10.1681/ASN.20090303 19

PMid:19713308 PMCid:PMC2754104

39. Winkelmayer WC, Liu J, Setoguchi S, Choudhry NK. Effectiveness and safety of warfarin initiation in older hemodialysis patients with incident atrial fibrillation. Clin J Am Soc Nephrol. 2011;6(11):2662-8.

http://dx.doi.org/ 10.2215/CJN.04550511

PMid:21959598 PMCid:PMC3206003

40. Ray WA. Evaluating medication effects outside of clinical trials: new-user designs. Am J Epidemiol. 2003;158(9):915-20.

http:/ / dx.doi.org/ 10.1093/aje/kwg231

PMid:14585769

41. Li J, Wang L, Hu J, Xu G. Warfarin use and the risks of stroke and bleeding in hemodialysis patients with atrial fibrillation: A systematic review and a meta-analysis. Nutr Metab Cardiovasc Dis. 2015;25(8):70613.

http:/ / dx.doi.org/10.1016/j.numecd.2015. 03.013

PMid:26026205

42. Patel MR, Mahaffey KW, Garg J, Pan G, Singer DE, Hacke $\mathrm{W}$, et al. Rivaroxaban versus warfarin in nonvalvular atrial fibrillation. N Engl J Med. 2011;365(10):883-91.

http://dx.doi.org/ 10.1056/NEJMoa10096 38

PMid:21830957

43. Granger $\mathrm{CB}$, Alexander JH, McMurray JJ, Lopes RD, Hylek EM, Hanna M, et al. Apixaban versus warfarin in patients with atrial fibrillation. N Engl J Med. 2011;365(11):981-92.

http://dx.doi.org/ 10.1056/NEJMoa1 1070 39

PMid:21870978

44. Connolly SJ, Ezekowitz MD, Yusuf S, Eikelboom J, Oldgren J, Parekh A, et al. Dabigatran versus warfarin in patients with atrial fibrillation. $N$ Engl $J$ Med. 2009;361(12):1139-51.

http://dx.doi.org/ 10.1056/NEJMoa09055 61

PMid:19717844
45. Chan KE, Edelman ER, Wenger JB, Thadhani RI, Maddux FW. Dabigatran and rivaroxaban use in atrial fibrillation patients on hemodialysis. Circulation. 2015;131(11):972-9.

http:/ /dx.doi.org/10.1161/CIRCULATIONA HA. 114.014113

PMid:25595139

46. Pollack CV, Jr., Reilly PA, Eikelboom J, Glund S, Verhamme P, Bernstein RA, et al. Idarucizumab for Dabigatran Reversal. N Engl J Med. 2015;373(6):511-20.

http://dx.doi.org/ 10.1056/NEJMoa15020 00

PMid:26095746

47. Knauf F, Chaknos CM, Berns JS, Perazella MA. Dabigatran and kidney disease: a bad combination. Clin J Am Soc Nephrol. 2013;8(9):1591-7.

http:/ / dx.doi.org/ 10.2215/CJN.01260213 PMid:23868901 PMCid:PMC3805067

48. Wilson JA, Goralski KB, Soroka SD, Morrison M, Mossop P, Sleno L, et al. An evaluation of oral dabigatran etexilate pharmacokinetics and pharmacodynamics in hemodialysis. J Clin Pharmacol. 2014;54(8):901-9.

http:/ / dx.doi.org/ 10.1002/jcph.335 PMid:24846496

49. Kubitza D, Becka M, Mueck W, Halabi A, Maatouk H, Klause N, et al. Effects of renal impairment on the pharmacokinetics, pharmacodynamics and safety of rivaroxaban, an oral, direct Factor $\mathrm{Xa}$ inhibitor. British J Clin Pharmacol. 2010;70(5):703-12.

http://dx.doi.org/10.1111/j.1365-

2125.2010.03753.x

PMid:21039764 PMCid:PMC2997310

50. Deal EN, Pope H, Ross W. Apixaban use among patients with severe renal impairment. Ann Pharmacother. 2014;48(12):1667.

http:/ / dx.doi.org/ 10.1177/ 106002801455 4446

PMid:25388542

51. Wang X, Tirucherai G, Marbury TC, Wang J, Chang $M$, Zhang $D$, et al. Pharmacokinetics, pharmacodynamics, and 
safety of apixaban in subjects with endstage renal disease on hemodialysis. J Clin Pharmacol. 2015.

http://dx.doi.org/10.1002/jcph.628

PMCid:PMC4418344

52. Hart RG, Pearce LA, Asinger RW, Herzog CA. Warfarin in atrial fibrillation patients with moderate chronic kidney disease. Clin J Am Soc Nephrol. 2011;6(11):2599-604. http:/ / dx.doi.org/ 10.2215/CJN.02400311 PMid:21903982 PMCid:PMC3359566

53. Palmer SC, Navaneethan SD, Craig JC, Johnson DW, Perkovic V, Hegbrant J, et al. HMG CoA reductase inhibitors (statins) for people with chronic kidney disease not requiring dialysis. Cochrane Database Syst Rev. 2014;5:Cd007784.

http:/ /dx.doi.org/ 10.1002/14651858.cd00 7784.pub2

54. Palmer SC, Navaneethan SD, Craig JC,
Johnson DW, Perkovic V, Nigwekar SU, et al. HMG CoA reductase inhibitors (statins) for dialysis patients. Cochrane Database Syst Rev. 2013;9:Cd004289.

http://dx.doi.org/ 10.1002/14651858.cd00 4289.pub5

55. Sibbald B, Roland M. Understanding controlled trials. Why are randomised controlled trials important? BMJ. 1998;316(7126):201.

http://dx.doi.org/10.1136/bmj.316.7126.2 01

PMid:9468688 PMCid:PMC2665449

56. Dentali F, Donadini MP, Clark N, Crowther MA, Garcia D, Hylek E, et al. Brand name versus generic warfarin: a systematic review of the literature. Pharmacotherapy. 2011;31(4):386-93. http://dx.doi.org/10.1592/phco.31.4.386 PMid:21449627 